九州大学学術情報リポジトリ

Kyushu University Institutional Repository

\title{
Effect of Enzymes on the Degree of Maceration of Soybean Fermented by Rhizopus Strains
}

Manurukchinakorn, Supranee

Laboratory of Food Technology, Faculty of Agriculture, Kyushu University

Fujio, Yusaku

Laboratory of Food Technology, Faculty of Agriculture, Kyushu University

https://doi.org/10.5109/24149

出版情報：九州大学大学院農学研究院紀要. 41 (3/4)，pp.231-237，1997-03. Kyushu University バージョン：

権利関係 : 


\title{
Effect of Enzymes on the Degree of Maceration of Soybean Fermented by Rhizopus Strains
}

\author{
Supranee Manurukchinakorn and Yusaku Fujio* \\ Laboratory of Food Technology, Faculty of Agriculture, \\ Kyushu University, Fukuoka 812, Japan \\ (Received October 1, 1996; Accepted December 17, 1996)
}

\begin{abstract}
Relationship between the degree of maceration (given in n-value) of fermented soybean and macerating enzyme formation was observed on raw and sterilized soybeans fermented for $12,24,36$ and $48 \mathrm{~h}$ at $30^{\circ} \mathrm{C}$ with 7 Rhizopus strains. Among 7 Rhizopus strains tested, Rhizopus oligosporus (TISTR3001, known as a dominant tempeh processing strain) gave the most powerful maceration degree (n-value in the equation, $\left.\mathrm{F}=\mathrm{C}\left(\Delta_{\varepsilon}\right)^{\prime \prime}\right)$ of $\mathrm{n}=1.4$ (initial value of 1.8) and $n=1.1$ (initial value of 1.7) for raw and sterilized soybeans respectively, for $48 \mathrm{~h}$ of fermentation Enzyme activities such as cellulase, pectinase, amylase and protease, markedly related to the degree of maceration. Among the enzyme formation, particularly both pectinase and cellulase gave the powerful maceration effect on the soybean fermented with Rhizopus since the formation of both enzymes coincided with the decrease of n-value.
\end{abstract}

\section{INTRODUCTION}

Several Rhizopus species are of considerable interest in the food and enzyme industry. They have been used in solid-state fermentation for several centuries, particularly in Asia for preparing many fermented foods such as tempeh from soybean (Cook, 1982; Hesseltine, 1965; Nout and Rombouts, 1990; Steinkraus, 1986). During fermentation, the initially hard tissue of the soybean converts to soft tissue by the maceration effect of fungal growth. The mycelium of Rhixopus can invade the intercellular lamella material and can solubilize it by extracellular enzymes (Nout and Rombouts, 1990). In spite of importance of the degree of maceration (softness or hardness) as an important factor for the quality of fermented soybean such as digestivity, texture and flavor, a few investigations (Jurus and Sundberg, 1976; Tsen et al., 1985) have reported regarding the degree of maceration of soybean during the fermentation in the past.

This paper deals with the relationship between the degree' of maceration and the change in enzyme formation during soybean fermentation by various Rhixopus strains.

\section{MATERIALS AND METHODS}

\section{Microorganisms}

Seven Rhixopus strains, i.e., four authentic Rhizopus strains (javanicus (IFO5442), oligosporus (TISTR3001), arrhizus (TISTR3247), sp. (UQM186F)) and three Rhixopus isolates (sp. All and sp. F98 from fermented foods, sp. LKN from tempeh starter) were used in this study.

\footnotetext{
* Corresponding author
} 


\section{Soybean}

Dehulled soybean (product of USA) was purchased from Kyuto Bussan Co. Ltd. (Fukuoka, Japan).

\section{Preparation of fermented soybean}

Raw and sterilized soybeans used as substrate were prepared and inoculated with desired Rhixopus strains by the method of Manurukchinakorn and Fujio (1997). Fermentation was carried out at $30{ }^{\circ} \mathrm{C}$ for $12,24,36$ and $48 \mathrm{~h}$.

\section{Measurement of the degree of maceration}

In accordance with Manurukchinakorn and Fujio (1997), the degree of maceration was determined by force-deformation test on bulk soybean specimen with a rheometer (R-UDJ-DM, Sun Kagaku Co. Ltd., Tokyo, Japan).

\section{Preparation of enzyme solution}

Enzyme formed was extracted by adding $100 \mathrm{ml}$ of distilled water to $50 \mathrm{~g}$ of the fermented soybean. The mixture was crushed and mixed thoroughly before placing in the cold room at $4{ }^{\circ} \mathrm{C}$ for $12 \mathrm{~h}$. The enzyme solution was obtained after squeezing of the crushed mixture mentioned above by using cheese-cloth and centrifugation at $12500 \mathrm{xg}$ for $20 \mathrm{~min}$.

\section{Determination of enzyme activities}

Enzyme activity was determined toward protease, amylase, cellulase and pectinase activities. For protease, reaction mixture was composed of $0.5 \mathrm{ml}$ crude enzyme solution and $2.5 \mathrm{ml}$ of haemoglobin solution ( $2 \%$ haemoglobin in acetate buffer $0.05 \mathrm{M}, \mathrm{pH} 4.5$ ). The reaction was done by incubation at $40^{\circ} \mathrm{C}$ for $20 \mathrm{~min}$ and the reaction was stopped by the addition of $4 \mathrm{ml}$ of $5 \%$ trichloroacetic acid. After removal of the undigested haemoglobin by filtration, the acid soluble products were determined with a spectrophotometer at $280 \mathrm{~nm}$. Protease activity was defined as the amount of enzyme solution which changed the reading at $280 \mathrm{~nm}$, equivalent to $1 \mu$ mole tyrosine per $\mathrm{mm}$ at 40 " $\mathrm{C}$. For amylase, reaction mixture was composed of $0.1 \mathrm{ml}$ of enzyme solution, $1 . \mathrm{O} \mathrm{ml}$ of $2 \%$ soluble starch solution and $1.0 \mathrm{Om}$ acetate buffer $(0.05 \mathrm{M}, \mathrm{pH} 5.0)$. The reaction was done by incubation at $40{ }^{\circ} \mathrm{C}$ for $10 \mathrm{~min}$. One unit of amylase activity was defined as $1 \mu$ mole reducing sugar (as glucose) released per min per $\mathrm{ml}$ of enzyme solution. For cellulase, reaction mixture was composed of $0.5 \mathrm{ml}$ enzyme solution, $1.0 \mathrm{ml}$ of $0.5 \%$ carboxymethylcellulose solution and $1.0 \mathrm{ml}$ of citrate buffer $(0.05 \mathrm{M}, \mathrm{pH} 5.5)$. The reaction was done by incubation at $40{ }^{\circ} \mathrm{C}$ for $20 \mathrm{~min}$. One unit of cellulase activity was defined as $1 \mu$ mole reducing sugar (as glucose) released per min per $\mathrm{ml}$ of enzyme solution. For pectinase (as polygalacturonase), reaction mixture was composed of $0.2 \mathrm{ml}$ enzyme solution, $1 . \mathrm{O} \mathrm{ml}$ of $1 \%$ pectic acid solution and $1 . \mathrm{O} \mathrm{ml}$ of phosphate buffer $(0.05 \mathrm{M}$, $\mathrm{pH}$ 7.0). The reaction was done by incubation at $40^{\circ} \mathrm{C}$ for $15 \mathrm{~min}$. The reducing sugar was determined by DNS method (Miller, 1959). One unit of pectinase activity was defined as $1 \mu$ mole reducing sugar (as $\alpha$-galacturonic acid) released per min per $\mathrm{ml}$ of enzyme solution. 


\section{RESULTS}

\section{Time course of the degree of maceration of fermented soybean}

The degree of maceration (Manurukchinakorn and Fujio, 1997) has been defined as the n-value in the equation, $\mathrm{F}=\mathrm{C}\left(\Delta_{\varepsilon}\right)^{\mathrm{n}}$, where $\mathrm{F}$ is force; $\mathrm{C}$ is constant and $\Delta \varepsilon$ is porosity change, by arrangement of measured force-deformation data of bulk specimen of fermented soybean, The smaller n-value in the equation corresponds to softer tissue.

Table 1 summarizes the n-values of raw and sterilized soybeans fermented by 7 strains of Rhixopus. The degree of maceration for raw and sterilized soybeans gave in initial n-value of 1.8 and 1.7, respectively. During fermentation, the tissue of fermented soybean became softer as shown by a decrease of $n$-value. The various $n$-values in Table 1 might be caused by different maceration abilities or growth rates of Rhizopus strains used. A tempeh strain, Rhixopus oligosporus (TISTR3001), gave the smallest n-value of 1.4 and 1.1 for raw and sterilized soybeans fermented at $30{ }^{\circ} \mathrm{C}$ for $48 \mathrm{~h}$, respectively. The Rhizopus sp. LKN also gave the smallest $\mathrm{n}$-value of 1.1 for sterilized soybean fermented at $30{ }^{\circ} \mathrm{C}$ for $48 \mathrm{~h}$.

Table 1. Summary of n-values from the logarithmic plots of force-porosity change.

\begin{tabular}{lccccc}
\multicolumn{7}{c}{ n-value } & \multicolumn{5}{c}{ raw soybean/sterilized soybean } \\
\hline \multicolumn{1}{c}{ Fermentation time (h) } & 0 & 12 & 24 & 36 & 48 \\
\hline Rhizopus sp.LKN & $1.8 / 1.7$ & $1.8 / 1.7$ & $1.8 / 1.5$ & $1.7 / 1.5$ & $1.6 / 1.1$ \\
Rhizopus sp.A11 & $1.8 / 1.7$ & $1.8 / 1.7$ & $1.8 / 1.7$ & $1.8 / 1.7$ & $1.7 / 1.6$ \\
Rhizopus sp.F98 & $1.8 / 1.7$ & $1.8 / 1.7$ & $1.8 / 1.5$ & $1.7 / 1.4$ & $1.7 / 1.4$ \\
Rhizopus sp.UQM186F & $1.8 / 1.7$ & $1.8 / 1.7$ & $1.8 / 1.7$ & $1.7 / 1.5$ & $1.6 / 1.4$ \\
R. javanicusIF05442 & $1.8 / 1.7$ & $1.8 / 1.7$ & $1.8 / 1.6$ & $1.7 / 1.6$ & $1.7 / 1.5$ \\
R. arrhizusTISTR3247 & $1.8 / 1.7$ & $1.8 \mathrm{~J} 1.7$ & $1.8 \mathrm{~J} 1.7$ & $1.7 / 1.7$ & $1.7 / 1.6$ \\
R. oligospomisTISTR3001 & $1.8 / 1.7$ & $1.8 \mathrm{~J} 1.7$ & $1.8 \mathrm{~J} 1.6$ & $1.7 / 1.6$ & $1.4 / 1.1$ \\
\hline
\end{tabular}

\section{Enzymatic changes in raw soybean}

The enzymes secreted with Rhixopus growth during fermentation will act on soybean maceration process. Fig. 1 (a, b, c, d) shows changes of enzyme activities with fermentation time on raw soybean. The protease activity (Fig. 1-a) varied markedly among 7 Rhixopus strains used. Fig. 1-b shows change of amylase activity with fermentation time. The high amylase activity may be caused by the inherent amylase in the raw soybean. Fig. 1-c and d show changes of cellulase and pectinase activities with fermentation time, respectively. At $48 \mathrm{~h}$ fermentation, Rhixopus oligosporus (TISTR3001) seemed to be the best producer of cellulase $(0.38 \mathrm{U})$ and pectinase $(3.38 \mathrm{U})$ on raw soybean among 7 Rhixopus strains tested. 


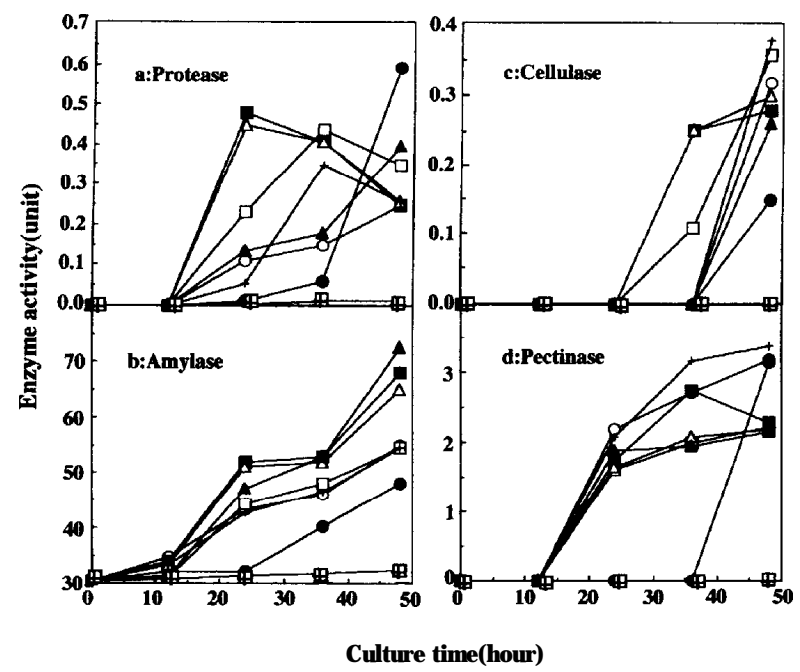

Fig. 1. Time courses of enzyme formation in the crude extract from raw soybean cultures of Rhizopus strains.

symbols: $\square$, control

, Rhizopus sp. Al 1

$\square$, Rhizopus sp. UQM186F

A, Rhizopus arrhizus TISTR3247
O, Rhizopus sp. LKN

, Rhizopus sp.F98

$\triangle$, Rhizopusjavanicus IF05442

+, Rhizopus oligosporus TISTR3001

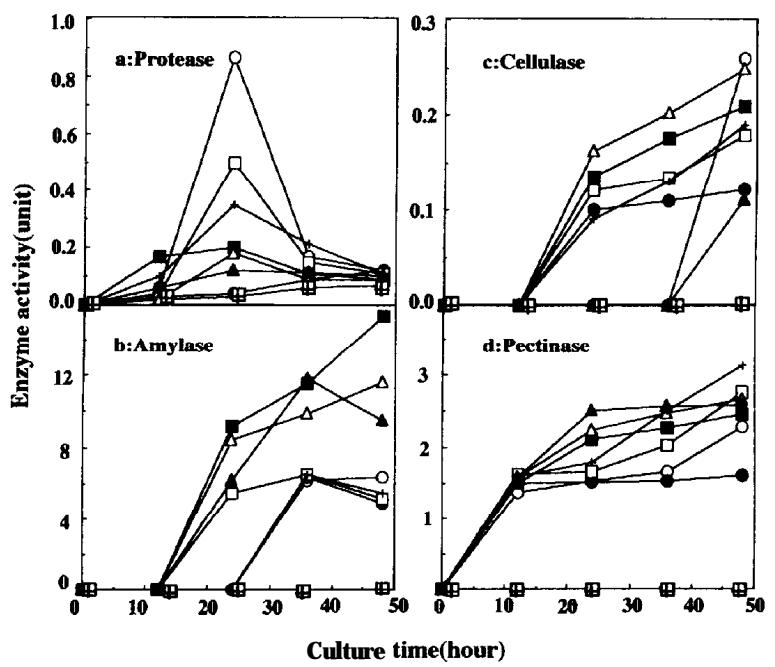

Fig. 2. Time courses of enzyme formation in the crude extract from sterilized soybean cultures of Rhizopus strains.

symbols: $\square$, control

, Rhizopus sp. All

$\square$, Rhizopus sp. UQM186F

A, Rhizopus arrhizus TISTR 3247
O,Rhizopus sp. LKN

, Rhizopus sp. F98

A, Rhizopusjavanicus IF05442

,+ Rhizopus oligosporus TISTR 3001 


\section{Enzymatic changes in sterilized soybean}

Fig. 2 (a, b, c, d) shows the formation of enzymes on sterilized soybean with fermentation time. As shown in Fig. 2-a, LKN, UQM186F and TISTR3001 produced big amount of protease and the activities reached to the maximum at $24 \mathrm{~h}$, then the steep decrease was observed. Fig. 2-b shows time courses of amylase formation which differ among strains tested. Fig. 2-c and d show time courses of cellulase and pectinase activities which increase with increase of fermentation time. At $48 \mathrm{~h}$ fermentation, Rhixopus sp. LKN seemed to be the best producer of cellulase (0.26U) while Rhixopus oligosporus (TISTR3001) was the best producer of pectinase (3.13U).

Comparing the enzyme formation on sterilized soybean with that on raw soybean, cellulase, pectinase and protease were formed at an earlier stage of fermentation time. The results suggest that Rhixopus strains tested can grow faster on sterilized soybean than raw soybean.

\section{Relationship between the degree of maceration and enzymes formed}

Fig. 3 shows the relationship between the degree of maceration (n-value) and cellulase and pectinase formation on soybean fermented by Rhizopus oligosporus (TISTR3001). During the fermentation, n-values of raw and sterilized soybeans decreased from 1.8 to 1.4 and 1.7 to 1.1, respectively. As shown in Fig. 3, the increase of cellulase and pectinase activities seemed to coincide with the decrease of n-values in both raw and sterilized soybeans. Despite sterilization or not, cellulase and pectinase are presumed to be the key enzymes in soybean maceration with Rhixopus growth.

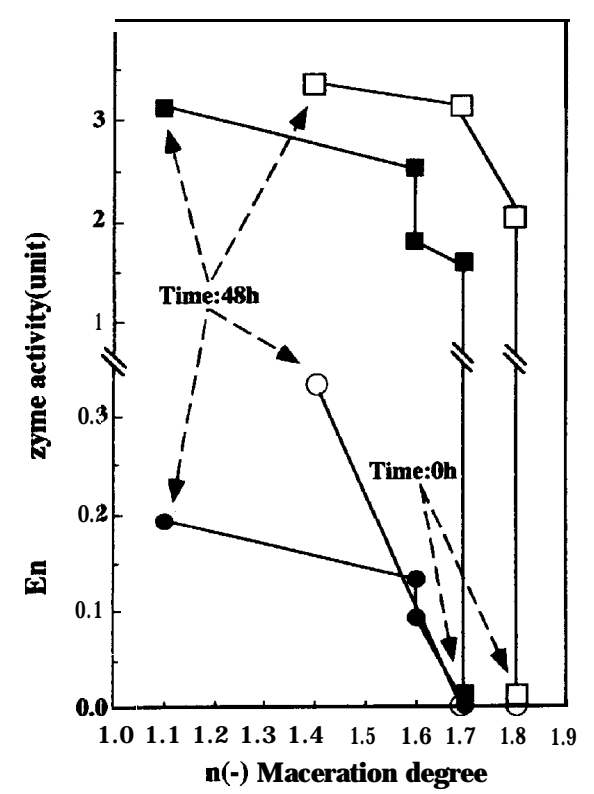

Fig. 3. Relationship between the degree of maceration and enzyme activity of soybean fermented by Rhizopus oligosporus TISTR3001. 


\section{DISCUSSION}

Soybean (Glycine $\max$ (L.) Merr.) mainly composed of protein, lipid, carbohydrate, etc. is normally considered as oil seeds in western countries while in oriental countries it is considered as edible seeds. Particularly, soybean is still provided as popular food supplying protein source for human in Asian countries such as China and Japan. One of soybean processing methods is fermentation with selected microorganisms (Tempeh in Indonesia with Rhizopus strain; Natto in Thailand, Nepal, Japan, etc. with Bacillus natto). Cotyledon of soybean becomes softer by fermentation and the resultant texture is desirable simultaneously with the elimination of mal odor from soybean (Whitaker, 1978). The softness of soybean foods is one of the quality limiting factors of foods. Nakamura et al. (1995) have revealed that enzymatic maceration of vegetables might be initiated with protopectinases action on partial depolymerization of the middle lamella. Thereafter, the plant material transformed into suspension of loose cells with shear force. To know the degree of soybean maceration with Rhizopus, a measure for softness or hardness was introduced by force-deformation relationship of bulk soybean (Manurukchinakorn and Fujio 1997). This measure has been defined as a power value, $n$ (a measure for softness), in an experimental equation, $\mathrm{F}=\mathrm{C}\left(\Delta_{\varepsilon}\right)^{\mathrm{n}}$ (where $\mathrm{F}$ is force; $\mathrm{C}$ is constant and $\Delta \varepsilon$ is porosity change). The maceration may follow the enzymes formed with fermentation and the enzyme activities may depend on the microorganisms and the potential of their enzyme formation. Within the limit of present experiment using Rhixopus strains, Rhixopus oligosporus TISTR3001 and sp. LKN showed the best capability for soybean maceration. This result might be caused by using two strains belonging to tempeh processing strain selected for soybean fermentation from of old. The enzymes related with maceration are presumed to be pectinase and cellulase. Pectinase and cellulase digest pectic substance and cellulose containing in soybean cotyledon as cementing material, respectively. The high amylase activity (Fig. 1-b) in the control of raw soybean at the beginning of fermentation may be caused by the inherent enzymes in soybean. Raw soybean contains abundant $\alpha^{-}$and pamylase (Ofelt et al., 1955; Learmonth and Wood, 1960; Pomeranz and Mamaril, 1964). Both amylases in raw soybean might have been activated while soaking raw soybean in $3 \%$ lactic acid solution at $30{ }^{\circ} \mathrm{C}$ for $3 \mathrm{~h}$ before inoculation.

\section{REFERENCES}

Cook, J. H. 1982 Cassava: a basic energy source in the tropics. Science, 218: 755-762

Hesseltine, C. W. 1965 A millennium of fungi, food and fermentation. Mycologia, 57: 149-197

Jurus, A. M. and W. J. Sundberg 1976 Penetration of Rhizopus oligosporus into soybeans in tempeh. Appl. and Envir. Microbiol., 32: 284-287

Learmonth, E. M. and J. C. Woos 1960 The influence of soya flour in read doughs. IV. Alpha-amylase of soya. Cereal Chemistry, 37: 158-169

Manurukchinakorn, S. and Y. Fujio 1997 Development of method for measuring the degree of maceration of soybean fermented with Rhizopus J.Fac.Agr., Kyushu Univ., 41: 105-1 15

Miller, G. L. 1959 Use of dinitrosalicylic acid reagent for determination of reducing sugar. Analyt. Chemistry, 39: 426-428

Nakamura, T., A. R. Hours and T. Sakai 1995 Enzymatic maceration of vegetables with protopectinases. $J$. Food Science, 60: 468-472 
Nout, M. J. R. and F. M. Rombouts 1990 Recent developments in tempeh research. J.Appl.Bacteriol., 69: 609-633

Ofelt, C. W., A. K. Smith and J. M. Mills 1955 Effect of soy flour on amylograms. Cereal Chemistry, 32: $48-52$

Pomeranz, Y. and F. P. Mamaril 1964 Effect of $N$-ethylmaleimide on the starch liquefying enzymes from soy flour. Nature, 203: 863-864

Steinkraus, K. H. 1986 Fermented foods, feeds, and beverages. Biotechnol. Advances, 4: 219-243

Tsen, H. Y., T. S. Lai and C. F. Hwang 1985 The changes of enzymatic activities and biochemical constituents during the fermentation of defatted soybean meal with Rhizopus thailandensis. II. Different fermentation conditions and the comparision of biochemical and rheological properties. $J$. Chin. Agr. Chem. Soc., 23: 300-307

Whitaker, R. J. 1978 Biochemical changes occuring during the fermentation of high-protein foods. Food Technol., 32: 175-180 